\title{
Determinants of User Intention toward IT Instruction: an Examination of Internal and External Factors
}

\author{
Show-Hui S. Huang*
}

Department of International Business \& Trade, Shu-Te University, 59 Hun Shan Rd, Kaohsiung county, Taiwan 824 R. O. C.

E-mail: hsheree@mail.stu.edu.tw

*Corresponding author

\section{Wen-Kai K. Hsu}

Department of Shipping Transportation \& Management, National Kaohsiung Marine University, No. 142, Haijhuan Rd., Kaohsiung City, Taiwan 811 R. O. C.

E-mail:khsu@mail.nkmu.edu.tw

\begin{abstract}
This paper discusses the internal and external factors that affect user intention to apply IT instruction. The internal factors were examined from the standpoint of user attitudes toward IT instruction, which included computer knowledge, perceived usefulness, and interest in applying IT instruction, while external factors included climate, school policy, facility, and training in IT instruction. The effects of participant demographics were also investigated. As an empirical study, 141 valid science and technology university teachers in Taiwan were surveyed for their experiences with teaching websites. The results indicate that all of the internal factors significantly affect teacher intention to apply IT instruction, but none of the external factors do, except for the climate variable. The results may help school administrators in promoting IT instruction.
\end{abstract}

Keywords: computer attitudes, intention, IT instruction, teaching websites.

Biographical notes: Show-Hui Huang has been an Associate Professor of the department of International Business and Trade at Shu-Te University since 2003. Dr. Huang received her ED. D. in 2003 from Idaho State University. She has published articles in Journal of Educational Computing Research, International Journal of Production Economics, and proceedings in the areas of information education, human resource training and development.

Wen-Kai Hsu is an Associate Professor of the Department of Shipping Transportation and Management at National Kaohsiung Marine University. Dr. Hsu was the Chairman of the department during 2005 to 2008. He received a Ph.D. degree from National Chung Kung University, Taiwan in 2000. His research interests include logistic management and information education. $\mathrm{He}$ has published articles in the following: Computer and Mathematic with Application, International Journal of Production Economics, OMEGA, Journal of Educational Computing Research. International Journal of Operations and Quantitative Management. 


\section{Introduction}

Computers and information technologies (IT) are rapidly becoming important components of modern life across the globe (Coffin \& MacIntyre, 1999). In schools, one of the most important sectors related to information technology is IT instruction (Calista, 2006). Generally, one of the most popular forms of IT is using digital teaching materials, such as PowerPoint slides. IT instruction may be broadly defined as teaching websites. By comparison with traditional teaching methods, there are many significant advantages for teaching websites, such as sharing teaching resources, timely updating of teaching materials, and lowering of teaching costs (Pituch \& Lee, 2006; Liaw, Huang \& Chen, 2007).

In developing IT instruction, many universities worldwide have implemented auxiliary teaching systems to support teachers in constructing their teaching websites, such as WebCT (World Wide Web Course Tools) and LMS (Learning Management System). However, construction of a teaching website does not mean that the implementation of IT instruction has been successful. It depends on whether users (teachers) use the teaching websites. User intention to continue using an IT instruction service is a major determinant of IT instruction success (Chiu et al., 2005). Hence, to promote IT instruction, in addition to implementing teaching websites, educational administrators may also need to consider how to improve teacher intention of using teaching websites in their instruction.

Most of the relevant research about user behaviors toward IT has focused on computer attitude, including anxiety (Dupagne \& Krendl, 1992) and computer selfefficacy (Compeau \& Higgins, 1995). However, the theory of reasoned action (TRA) and the theory of planned behavior (TPB) argue that individual behavior is determined by individual intention, and this intention is a function of attitude (Ajzen, 1985; Ajzen, 2002). Hence, in promoting IT instruction, improving teacher intention toward IT instruction should be an important issue for school administrators.

As determinants of teacher intention to apply IT instruction, most previous research has emphasized internal factors, such as gender, age, learning experience, computer knowledge, and individual computer facilities. However, certain external factors may also affect teacher behavior in applying a new IT instruction, including the climate of IT instruction among colleagues, and school policies to support IT instruction. Thus, to more completely examine the factors that influence teacher intention toward IT instruction, incorporating such external factors is essential. In the relevant studies, few articles simultaneously discuss both internal and external determinants.

The purpose of this study is to discuss user intention to apply IT instruction, in which the IT instruction is focused on the applications of teaching websites. First, user intention to apply IT instruction is discussed, followed by an examination of the factors that affect intention, including both internal and external determinants of user intention. To validate the research model, 141 science and technology university teachers in Taiwan were surveyed. 


\section{Literature Review}

The purpose of this paper is to discuss the internal and external factors that affect teacher intention to apply IT instruction. Accordingly, the relevant research will be reviewed below.

\subsection{Teacher Intention toward IT Instruction}

The models of TRA and TPB posit that individual behavior is determined by individual intention, and this intention is a function of attitude (Ajzen, 1985; Ajzen, 2002). Therefore, intention is the major factor affecting behavior, while attitude is an indirect determinant. The intention variable has been widely explored in studies of student use of a specific IT, such as WWW (Lederer, Maupin, Sena \& Zhuang, 2000), library system (Hong et al., 2002), and e-learning (Ong \& Lai, 2006; Pituch \& Lee, 2006; Liaw, Huang \& Chen, 2007; Ngai, Poon \& Chan, 2007). Based on the TRA and TPB, this paper focuses on teacher intention to apply a new IT instruction in teaching, in which the IT is defined as a teaching website.

\subsection{Internal Factors}

The models of TRA and TPB posit that individual behavior is determined by individual intention, and this intention is a function of attitude (Ajzen, 1985; Ajzen, 2002). Therefore, intention is the major factor affecting behavior, while attitude is an indirect determinant. The intention variable has been widely explored in studies of student use of a specific IT, such as WWW (Lederer, Maupin, Sena \& Zhuang, 2000), library system (Hong et al., 2002), and e-learning (Ong \& Lai, 2006; Pituch \& Lee, 2006; Liaw, Huang \& Chen, 2007; Ngai, Poon \& Chan, 2007). Based on the TRA and TPB, this paper focuses on teacher intention to apply a new IT instruction in teaching, in which the IT is defined as a teaching website.

Generally, users with higher computer knowledge have stronger computer selfefficacy (or lower anxiety). Thus, computer knowledge could be a determinant of selfefficacy (or anxiety). Previous studies have found that the level of computer knowledge of users is an important factor affecting their computer self-efficacy (Hartwick \& Barki, 1994). Therefore, instead of self-efficacy and anxiety, the computer knowledge of users is employed to define the first internal factor in this paper. Computer knowledge has been shown to have significant direct and indirect effects on user attitude and intention in previous research, with library users (Hong, Thong, Wong \& Tam, 2002), and employees of small-scale business (Thong, 1999).

In addition to computer self-efficacy and anxiety, there are other definitions for user attitudes toward IT (computers), such as subjects' perceived usefulness (Davis, 1989) and interest (computer liking) (Kay, 1993). The Technology Acceptance Model (TAM) (Davis, 1989) indicates that the perceived usefulness of a new IT had significantly positive effects on user intention to apply the IT. This result has supported by numerous studies (Lederer et al., 2000; Hong et al., 2002; Wixom \& Todd, 2005; Ong \& Lai, 2006; Pituch \& Lee, 2006; Liaw, Huang \& Chen, 2007; Ngai et al., 2007). In addition to perceived usefulness, Muhammad and Ibrahim (1998) concluded that the interest of subjects in computers significantly affected their level of confidence, usage, and anxiety toward computers. Schunk's (1996) indicated that interest is one of the primary sources of learning motives. Liaw et al. (2007) also indicated that enjoyment would affect teacher 
intention to use e-learning. Thus, the perceived usefulness and interest of teachers in IT instruction are also employed as internal factors in this study.

\subsection{External Factors}

This study defines the external factors as climate (how much IT instruction is applied among colleagues), school policy, facilities, and training in IT instruction. Most of the related research has concentrated on training and facilities. For example, Mikkelsen et al. (2002) found that training was the most significant factor in improving employee attitudes toward use of new IT. Yaghi and Abu-Saba (1998) and Hakkinen's study (1994) concluded that the computer anxiety of subjects was diminished by increasing their experience and giving them training. Torkzadeh and Van Dyke (2002) indicated that training had a significant effect on the internet self-efficacy of users. Regarding the facility factor, studies have shown that people who have access to computer facilities at home tend to develop more computer knowledge and confidence (Geissler \& Horridge, 1993; Nichols, 1992, Rocheleau, 1995).

Compared to training and facility factors, climate and school policy factors have been less explored in research into user intention toward an IT. User behaviors have been primarily described in terms of subjective norms, defined as the support of subjects' colleagues, direct managers, and top managers (Davis, Bagozzi \& Warshaw, 1992; Cale \& Eriksen, 1994; Teo, Wei \& Benbasat, 2003; Amold et al., 2006). A review of literature shows that subjective norms significantly affect user intention to use a certain IT (Taylor \& Todd, 1995; Igbaria, Guimaraes \& Davis, 1995; Karahanna \& Straub, 1999).

\section{Methodology}

\subsection{Research Model}

The purpose of this paper is to discuss the internal and external factors that affect teacher intention to apply IT instruction. Firstly, IT instruction is defined as teaching websites. The research model is then constructed (Figure 1). The internal factors are defined as users' computer knowledge, interest, and perception of usefulness in applying IT instruction, while external factors consist of climate, school policy, facility, and training in IT. Further, the effects of participant demographics on intention are also discussed in this paper.

Based on the research model, several research hypotheses are constructed. For the effects of internal factors $\left(\mathrm{H}_{1}\right)$, the following three hypotheses were constructed:

$\mathrm{H}_{1 \mathrm{a}}$ : Knowledge has a significant effect on Intention.

$\mathrm{H}_{1 \mathrm{~b}}$ : Usefulness has a significant effect on Intention.

$\mathrm{H}_{1 \mathrm{c}}$ : Interest has a significant effect on Intention. 


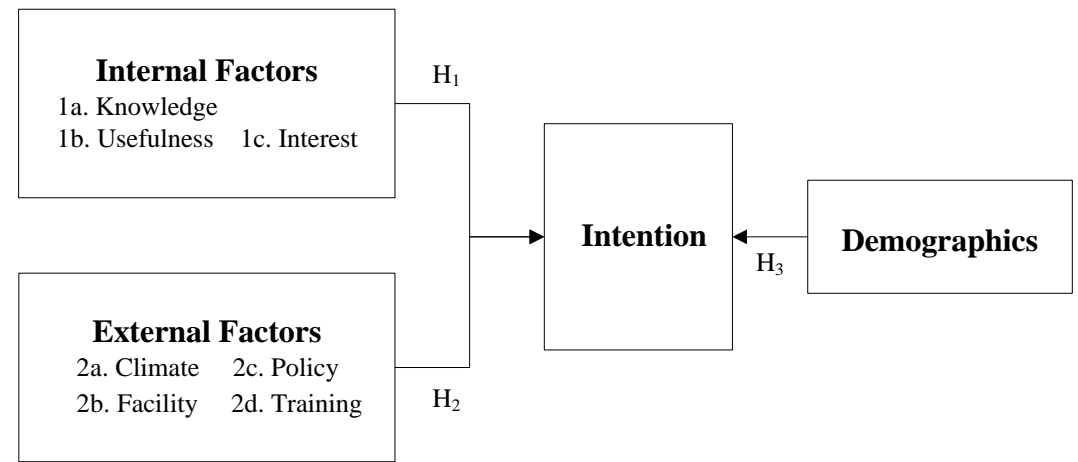

Figure 1. The Research Model

For the effects of external factors $\left(\mathrm{H}_{2}\right)$, four hypotheses are created:

$\mathrm{H}_{2 \mathrm{a}}$ : Climate has a significant effect on Intention.

$\mathrm{H}_{2 \mathrm{~b}}$ : Policy has a significant effect on Intention.

$\mathrm{H}_{2 \mathrm{c}}$ : Facility has a significant effect on Intention.

$\mathrm{H}_{2 \mathrm{~d}}$ : Training has a significant effect on Intention.

Finally, for demographics, we hypothesize:

$\mathrm{H}_{3}$ : User demographics significantly affect intention to apply IT instruction.

\subsection{Research Instrument}

According to the research model, a self-reported survey was designed. There were two scales and one demographic section in the survey. All of the scales were designed with a 5 -point Likert scale ( $5=$ strongly agree; $4=$ agree; $3=$ uncertain; $2=$ disagree; $1=$ strongly disagree) to determine subject agreement with each statement. Higher scores represent greater agreement with each statement. The negative statements are reversed when scored. Thirty teachers from Su-Te University in Taiwan were used to pretest the survey.

\subsubsection{The Scale of Determinants}

This survey comprises two parts, the internal and external scales. The former was modeled after the surveys by Levine and Donitsa-Schmidt (1998) and Mikkelsen et al. (2002). The latter was revised using questionnaires by Mikkelsen et al. (2002). Factor analysis with the principal component method and varimax rotation was conducted to identify and extract factor dimensions from the pretest samples. After eliminating 3 statements for being ambiguous, 6 dimensions with eigenvalues $>1$ were extracted. By the factor loadings of statements, those dimensions are termed Knowledge (4 items), Interest (3 items), Usefulness (3 items), Climate (4 items), Policy (3 items), and Facility (3 items). In addition, Cronbach's $\alpha$ was employed to verify the reliabilities of the 6 dimensions.

The training variable, measured in the demographic section, was defined as any kind of training activity in IT instruction which subjects had attended for the last 3 years, such as seminars, conferences, workshops and classes. The measurement of the training variable was classified into four levels based on training hours ( $4=$ over 16 hours; $3=9$ 16 hours; $2=1-8$ hours and $1=0$ hour). 


\subsubsection{The Intention Scale}

This part of the questionnaire was modeled after Hong et al. (2002). Factor analysis and Cronbach $\alpha$ are also employed to validate and verify the reliability of the scale. After eliminating 2 statements, the remaining 5 items converged on one dimension, which was named as Intention.

\subsubsection{The Demographic Section}

In addition to training, there were five demographic characteristics in this part of the survey: gender, school, department, age, and seniority. The department feature consists of five categories: management, engineering, nursing, humanities and computer science. There are two categories in the school feature which are public and private schools.

\subsection{Population and Sample}

Table1: Effects of Demographics on Intention by Factor Scores

\begin{tabular}{|c|c|c|c|}
\hline Category & Tests & Percentage & Intention \\
\hline \multirow{4}{*}{ Gender } & Levene's test Sig. & & .390 \\
\hline & $T$-test Sig. & & .821 \\
\hline & Male & $61.7 \%$ & -.015 \\
\hline & Female & $38.3 \%$ & -.024 \\
\hline \multirow{4}{*}{ School } & Levene's test Sig. & & .877 \\
\hline & $T$-test Sig. & & .222 \\
\hline & Public & $17.0 \%$ & -.228 \\
\hline & Private & $83.0 \%$ & .046 \\
\hline \multirow{6}{*}{ Age } & Levene's test Sig. & & .189 \\
\hline & ANOVA Sig. & & $.049 *$ \\
\hline & Under 30 & $3.5 \%$ & $.184^{\mathrm{a}}$ \\
\hline & $31-40$ & $53.9 \%$ & .162 \\
\hline & $41-50$ & $33.3 \%$ & -.273 \\
\hline & over 51 & $9.2 \%$ & $-.561^{b}$ \\
\hline \multirow{7}{*}{ Department } & Levene's test Sig. & & .793 \\
\hline & ANOVA Sig. & & $.012 * *$ \\
\hline & Management & $41.8 \%$ & $.439^{\mathrm{a}}$ \\
\hline & Engineering & $20.6 \%$ & -.082 \\
\hline & Nursing & $17.7 \%$ & $-.292^{b}$ \\
\hline & Humanity & $9.2 \%$ & -.127 \\
\hline & Computer & $10.6 \%$ & $.711^{\mathrm{a}}$ \\
\hline \multirow{6}{*}{$\begin{array}{l}\text { Training } \\
\text { (hours) }\end{array}$} & Levene's test Sig. & & .119 \\
\hline & ANOVA Sig. & & .844 \\
\hline & None & $39.0 \%$ & -.045 \\
\hline & $1-8$ & $24.1 \%$ & -.009 \\
\hline & $9-16$ & $21.3 \%$ & -.015 \\
\hline & over 16 & $15.6 \%$ & .007 \\
\hline \multirow{2}{*}{ Seniority } & Test Sig. & & $.017 *$ \\
\hline & Pearson Corr. & & -.200 \\
\hline
\end{tabular}

Note. ${ }^{*} p<.05, * * p<.01$, and ${ }^{\mathrm{a}},{ }^{\mathrm{b}}$ denotes mean factor scores of the significant groups using Post Hoc test. 
The research population consisted of all full time teachers of science and technology universities in Taiwan. In Taiwan, the majority of students of those universities are from vocational high schools. The educational aims of these universities are mostly focused on occupational skills and technology training for students. Based on the approximately 1:4 ratio of public and private schools in this area, samples were drawn randomly from 2 public and 8 private schools with 5 subjects for each department. A personally distributed survey method was applied in this study. All the participants in the study were asked to participate voluntarily and anonymously. The total sample size was 500 subjects with 50 for each school. The total number of valid responses was 141. In the valid sample, $61.7 \%$ were male teachers, $38.3 \%$ were female. The rates of public and private schools were $17.0 \%$ and $83.0 \%$, respectively. The average seniority of teachers was 6.51 years (S.D. = 5.24). Other demographic data (age, teaching department, and training hours) are shown in the third column of Table 1.

\subsection{The Validation and Reliability of the Survey}

Factor analysis with the principal component method and varimax rotation was employed to validate the survey scale. The results of the scale of determinants are shown in Table 2, while Table 3 shows the results for the intention scale. The factor dimensions extracted from those two scales were the same as those of the pretest. The variances explain $73.30 \%$ of the variance for the scale of determinants, and $60.50 \%$ for the intention scale. The reliabilities (Cronbach $\alpha$ ) are 0.883, 0.851, 0.862, 0.761, 0.793, 0.802 for the dimensions of determinants, respectively, and 0.883 for the intention dimension. The above results indicate that the questionnaire has validity and reliability. The mean scores for each dimension are also shown in Tables 2 and 3, respectively.

Table 2: Reliability and Validity of Scales

\begin{tabular}{|c|c|c|c|c|c|c|}
\hline \multirow{2}{*}{ Statements } & \multicolumn{6}{|c|}{ Factor Dimensions } \\
\hline & $K$ & $U$ & $I$ & $\bar{C}$ & $P$ & $F$ \\
\hline I know LAN, Databases, and network well. & .735 & .261 & .119 & .208 & .085 & .156 \\
\hline I know how to download and upload data from websites. & .790 & .056 & .254 & .259 & -.070 & .165 \\
\hline I am familiar with searching information on the internet. & .792 & -.002 & .331 & .216 & .007 & .178 \\
\hline $\begin{array}{l}\text { I am familiar with website construction software such as } \\
\text { Frontpage. }\end{array}$ & .803 & .163 & .183 & .215 & .044 & -.024 \\
\hline $\begin{array}{l}\text { I feel teaching websites can improve my teaching } \\
\text { effectiveness. }\end{array}$ & .021 & .758 & .193 & .287 & .058 & .144 \\
\hline I feel teaching websites can save me a lot of time. & .178 & .884 & .220 & .088 & .058 & -.025 \\
\hline I feel teaching websites are very useful for my teaching. & .154 & .869 & .123 & -.037 & .104 & .013 \\
\hline $\begin{array}{l}\text { I am interested in attending a conference or workshop about } \\
\text { teaching websites. }\end{array}$ & .270 & .224 & .703 & .249 & .056 & -.198 \\
\hline $\begin{array}{l}\text { I pay attention to new IT product ads when reading } \\
\text { newspapers or magazines. }\end{array}$ & .285 & .251 & .807 & .175 & .074 & .028 \\
\hline I like to go to new IT product shows. & .239 & .172 & .859 & .095 & -.055 & .094 \\
\hline $\begin{array}{l}\text { In my department, many teachers use teaching websites in } \\
\text { teaching. }\end{array}$ & .159 & .155 & .235 & .728 & .002 & .181 \\
\hline $\begin{array}{l}\text { In my department, many teachers post class materials on } \\
\text { websites. }\end{array}$ & .097 & .194 & .098 & .795 & -.002 & -.115 \\
\hline $\begin{array}{l}\text { In my department, many teachers construct teaching } \\
\text { websites. }\end{array}$ & .372 & .036 & -.022 & .703 & -.021 & .096 \\
\hline Use teaching websites is popular in my department. & .286 & -.072 & .190 & .627 & .078 & .103 \\
\hline
\end{tabular}




\begin{tabular}{|c|c|c|c|c|c|c|}
\hline $\begin{array}{l}\text { My school strongly supports teachers to use teaching } \\
\text { websites in teaching. }\end{array}$ & -.002 & .088 & -.007 & .025 & .739 & .295 \\
\hline $\begin{array}{l}\text { My school encourages teachers to attend IT instruction } \\
\text { workshops. }\end{array}$ & .002 & .040 & -.054 & .035 & .891 & .186 \\
\hline $\begin{array}{l}\text { My institution provides enough IT instruction workshops for } \\
\text { teachers. }\end{array}$ & .037 & .069 & .090 & -.012 & .778 & .079 \\
\hline I can easily access tools for teaching websites. & .124 & .106 & -.072 & .100 & .060 & .804 \\
\hline $\begin{array}{l}\text { My school provides enough teaching website tools for } \\
\text { teachers to use. }\end{array}$ & .101 & .042 & .005 & .010 & .341 & .810 \\
\hline $\begin{array}{l}\text { My school provides enough website spaces for teachers to } \\
\text { use. }\end{array}$ & .113 & -.046 & .077 & .070 & .239 & .782 \\
\hline Mean Score & 3.587 & 4.310 & 3.667 & 3.761 & 3.314 & 3.102 \\
\hline Cumulative Variance (\%) & 14.99 & 27.30 & 39.55 & 51.20 & 62.51 & 73.37 \\
\hline Cronbach's $\alpha$ & .883 & .851 & .862 & .761 & .793 & .802 \\
\hline
\end{tabular}

Note. K: Knowledge, U: Usefulness, I: Interest, C: Climate, P: Policy and F: Facility.

Table 3: Reliability and Validity of Intention Scale

\begin{tabular}{lccc}
\hline \multicolumn{1}{c}{ Statements } & $\begin{array}{c}\text { Factor } \\
\text { Loading }\end{array}$ & $\begin{array}{c}\text { Explaine } \\
\mathrm{d} \\
\text { Variance }\end{array}$ & $\begin{array}{c}\text { Cronbac } \\
\mathrm{h} \\
\alpha\end{array}$ \\
\hline I like to apply teaching websites in teaching. & .791 & & \\
$\begin{array}{l}\text { I have the intention to learn and construct a teaching } \\
\text { website. }\end{array}$ & .759 & & \\
I like to learn skills about teaching websites. & .777 & 60.50 & .833 \\
$\begin{array}{l}\text { I will try to learn the advanced functions of a teaching } \\
\text { websites. }\end{array}$ & .788 & & \\
I will attend trainings about teaching websites. & .775 & & \\
\hline
\end{tabular}

\subsection{Data Analysis}

The factor scores for the dimensions of determinants and intention were yielded first. Then, multiple linear regression analysis was employed to analyze how the dimensions of determinants affected teacher intention to apply IT instructions. Finally, Levene's test, one way ANOVA ( $t$-test), and Scheffe's post hoc test were employed to reveal the effects of demographic variables on intention. An alpha $=0.05$ was applied for all the above statistical tests.

\section{Results and Discussions}

The Regression Analysis was applied in this study to test if the external and internal factor dimensions significantly affected teacher intention to apply IT instruction. The normal probability plots and scatter plots of residuals for the above regression analysis are shown in the Appendix (Figure A). The normal probability plots of residuals closely resembled diagonal lines and the residual plots were scattered uniformly in the interval [$3,3]$. The above results indicate that the assumptions of the regression analysis basically held. 
The results of regression analysis (Table 4) indicate that all of the internal factors significantly affect teacher intention to apply IT instruction, but the external factors generally do not. Except for the climate factor, external factors did not have any significant effect on teacher intention to apply IT instruction. The regression model explains the variance of intention $48.8 \%$ with an adjusted $R^{2}=46.9 \%$.

Table 4: Determinants of Teacher Intention to Apply IT Instruction

\begin{tabular}{lcccc}
\hline \multicolumn{1}{c}{ Factors } & $\begin{array}{c}\text { Standardized } \\
\text { Coefficients }(\beta)\end{array}$ & $t$ & $p$-value & $R^{2} /$ Adj. $R^{2}$ \\
\hline (Constant) & .226 & .000 & 1.000 & \\
Knowledge & .526 & 8.847 & $.000^{* *}$ & \\
Usefulness & .386 & 6.965 & $.000^{* *}$ & \\
Interest & .248 & 4.231 & $.000^{* *}$ & $48.8 \%$ \\
Climate & -.021 & -.366 & .715 & \\
Policy & -.016 & -.270 & .788 & \\
Facility & & & & \\
Note. $* p<.05, * * p<.01$. & & &
\end{tabular}

\subsection{The Effects of Internal Factors}

The results indicate that all of the internal factor dimensions significantly affected teacher intention to apply IT instruction. The perceived usefulness $(\beta=.526$, and $p<.01)$ is the most significant factor in teacher intention to apply IT instruction. This result is consistent with previous research on the TAM (Davis, 1989; Lederer et al., 2000; Gefen \& Straub, 2003; Wixom \& Todd, 2005; Pituch \& Lee, 2006; Liaw et al., 2007) which found that users' perceived usefulness of a given IT had a significant effect on their intention to use the IT. Therefore, to encourage usage of IT instruction, school authorities may consider enhancing teacher perceptions of IT usefulness.

Teacher interest $(\beta=.386$, and $p<.01)$ is another internal factor that significantly affects intention to apply IT instruction. This result is consistent with the findings of Liaw et al. (2007) that interest has a positive effect on user intention to use an e-learning system. Generally, when individuals are interested in IT, they will spontaneously devote more time to learning it. This spontaneous learning behavior is the most efficient force driving teachers to apply IT instruction. In addition to perceived usefulness and interest, computer knowledge of teachers also has a significant positive effect on their intention to apply IT instruction $(\beta=.226$ and $p<.01)$. This result also supports previous studies (Venkatesh \& Davis, 1996; Thong, 1999; Hong et al., 2002). Generally, when an individual has knowledge of something, they will feel more confident about it. In practice, using auxiliary teaching systems, it may not be difficult for teachers to construct their teaching websites. However, for some advanced applications, users may be required to possess more computer knowledge.

\subsection{The Effects of External Factors}


Most of the external factors did not significantly affect teacher intention to apply IT instruction. First, the training factor was tested by running ANOVA (Table 1). The results indicate that training factor did not have any effect on teacher intention to apply IT instruction. This result is clearly different from those of previous studies (Torkzadeh \& Van Dyke, 2002; Mikkelsen et al., 2002; Yaghi \& Abu-Saba, 1998; Hakkinen, 1994). This paper measure the training variable by the hours that subjects had attended training activities over the last 3 years. Practically, in addition to training hours, the learner (teacher) attitude may also be a determinant of training effect. Generally, a positive learning attitude can drive learners to put more effort into learning the training courses. The results in Table 1 indicate that about $85 \%$ (84.6\%) of teachers had attended less than 2 days (16 houses) of training for IT instruction in the last 3 years, and 39\% of teachers had never undergone such training. This result implies that the participants' attitudes toward attending training programs do not appear to be positive. Furthermore, the training content may also be a factor affecting the training performance. Usually, a poor training program may not yield expected training effects, even if the user has enough training time.

Of external factors, neither the policy nor facility factors significantly affected the attitudes of teachers in applying IT instruction. Climate was the only external factor that had significant (positive) effect on teacher intention to apply IT instruction ( $\beta=.248$ and $p<.01)$. The above results implied that, for promoting teachers to apply IT instruction, creating atmosphere on IT instruction among colleagues may be more effective than offering them training opportunities or teaching facilities. This result may be also explained that the climate can develop external pressures to push teachers to apply IT instruction.

To summarize, all of the 3 hypotheses for $\mathrm{H}_{1}\left(\mathrm{H}_{1 \mathrm{a}}, \mathrm{H}_{1 \mathrm{~b}}\right.$ and $\left.\mathrm{H}_{1 \mathrm{c}}\right)$ are confirmed, and for hypothesis $\mathrm{H}_{2}$, only the $\mathrm{H}_{2 \mathrm{a}}$ is verified.

\subsection{The Effects of Demographics}

To validate Hypothesis 3, Levene's tests were employed to test the assumptions of homogeneity of variance for all the demographic factors except seniority. The results shown in Table 1 indicate that all of the tests were not significant, this point out that the assumptions were held. Therefore, a $t$-test was then employed to test the significances of gender and school factors, and ANOVA was applied to test the significance of age and department variables. For the significant factors of the tests, Scheffe's post hoc tests were then performed. Finally, the Pearson Correlation method was used to test if seniority characteristic significantly affected teacher intention. The results of those analyses are also shown in Table 1.

As shown in Table 1, the gender factor does not have significant effect on teachers' intention to apply IT instruction $(p=.821>0.05)$. This result is different from many previous researches about males are more experienced with and more positive towards computers and related attitudes (Whitely, 1997; Ventatesh \& Morris, 2000; Ong \& Lai, 2006) the age factor has significant effect on the intention of teachers to apply IT instruction $(p=.049<0.05)$, and the Post Hoc tests showed that the intention decreased by their age. The intention of teachers who are under 30 years old was significantly higher than those who are over 50 years old. The same pattern exists in respect of the seniority factor. More senior teachers also appeared to have less intention to apply IT instruction $(r=-.200, p=.017<0.05)$. It is obvious for older and senior teachers to be 
less motivated to implement IT instruction because they have been accustomed to traditional teaching methods. They may not want to adopt new instructional methods.

For the department factor, the results indicate that the intention of teachers in nursing department to use IT instruction was also significantly lower than the intention of teachers in computer and management departments. The results are consistent with the findings of Marcoulides (1989) that subjects majoring in humanity and social sciences have higher computer anxiety than those majoring in science and business. To sum up the above result, the Hypothesis 3 in Figure 1 was also partly confirmed.

\section{Conclusions and Recommendations}

The purpose of this paper is to discuss the internal and external factors that affect science and technology teacher intention to apply IT instruction. The results indicated that, among the internal factors, the perception of usefulness was the most significant factor in increasing teacher intention to apply IT instruction. Climate was the only external factor to significantly affect teacher intention to use IT instruction. Generally, a useful technology is based on user-driven data, and perceived usefulness may create interest in IT instruction and address the lack of willingness to attend training programs. This paper suggests that experience sharing among colleagues can improve teacher perception of the usefulness of IT instruction. Colleagues who are able to apply IT instruction skillfully can be invited to explain the benefits of IT instruction to users, such as saving time in preparing handouts, updating, and keeping teaching materials much easier, and enriching teaching contents. In general, people are likely to accept richer explanations of substantial benefits. Furthermore, a good symposium of experience sharing may also improve the climate for applying IT instruction.

Results also indicated that computer knowledge and interest were significant factors in improving teacher intention to apply IT instruction. Generally, the computer knowledge of teachers develops out of their individual study and/or attending extra training. Practically, individual study may be related to teacher interests.

Results showed that, except for climate, external factors did not have any significant effect on teachers' intention to apply IT instruction. In Taiwan, the Ministry of Education spends a great deal of money to support training workshops and equipment for IT instruction. However, these policies do not seem to be effective in improving teacher intention to apply IT instruction. Thus, those support policies may need to be reconsidered. This paper suggests that substantial support should be offered to improve teacher attitude toward attending training, such as subsidization of registration fees, transportation, and lodging costs, and offering training days off. Such support may improve teacher attitude toward attending the training. Furthermore, incorporating training records into teacher performance appraisal may be another way to improve teacher attitude towards attending training. In Taiwan, a similar performance appraisal system has been applied to encourage teachers in high schools in lifelong learning. The system maintains records of teacher learning performance. Given such negative and positive incentives, teachers will then pay more attention to training activities. Further, the content of training programs may be another factor affecting training performance. Thus, the design of training courses should be considered. A good training program not only can initiate user interest in learning IT instruction, but can also improve their perceived usefulness of IT instruction, and as a result, increase users intention to apply the IT instruction. 
The demographic results indicate that teachers in management and computer departments have a more positive intention to apply IT instruction than those in the humanity and nursing departments. In Taiwan, basic computer courses, such as data processing, have become fundamental courses for almost all departments. Generally, in humanities and nursing departments, those courses are supported and conducted by teachers from the computer science departments. This paper suggests that these departments, at least, employ a full time teacher with a computer science background. Further, when teaching the basic computer courses, the instructor could also assist other instructors in learning the new IT.

In research regarding user behavior in IT implementation, the Technology Acceptance Model (TAM) (Davis, 1989) has been widely used. TAM explains how user exogenous variables affected their intentions to use a certain IT system based on two intermediate variables, perceived ease of use and perceived usefulness. In TAM, the exogenous variables are not defined clearly. Later studies have described the exogenous variables based on their sample populations (Igbaria, Iivari \& Maragahh, 1995; Hong et al., 2002). In this paper, the exogenous variables were more thoroughly investigated from the perspective of user internal and external factors, and perceived usefulness was included in the internal factors. However, constructing a causal model to analyze teacher behavior in apply IT instructions may be a topic for further research. Furthermore, the students, the recipients of IT instruction, are not discussed in this paper. In practice, the attitudes of both teachers and learners may affect the performance of IT instruction. Thus, the effect of learner factor should be a topic for further research.

In this information era, computer and information technology education has become a key curriculum in universities all over the world. This paper discusses teacher attitudes toward IT instruction using an empirical study. The results provide information for school administrators in promoting IT instruction. Further, the research model, especially important factors, offers a useful reference for related research.

\section{Acknowledgements}

The authors greatly appreciate the anonymous reviewers for their very valuable and helpful comments on the earlier version of this paper. Further, this paper was partly funded by National Science Council of Taiwan as NSC 93-2520-S-366-001.

\section{References}

1. Ajzen, I. (1985). From Intentions to Action: A Theory of Planed Behavior. In J, Kuhl and J. Beckmann (eds.), Action Control: From Cognition to Behavior. New York: Springer-Verlag, 11-39.

2. Ajzen, I. (2002). Perceived behavioral control, self-efficacy, locus of control and theory of planned behavior, Journal of Applied Social Psychology, 32, 1-20.

3. Amold, J., Loan-Clark, J., Coombs, C., Wilkinson A., Park J., \& Preston, D. (2006). How well can the theory of planned behavior account for occupational intentions, Journal of Vocational Behavior, 69(3), 374-390.

4. Bekers, J., \& Schmidt, H. (2001). The structure of computer anxiety: A Six Factor model. Computers in Human Behavior, 17(1), 35-49. 
5. Cale, E., \& Eriksen, S. (1994). Factors affecting the implementation outcome of a mainframe software package: A Longitudinal study. Information and Management, 36(3), 165-175.

6. Calista, D. J. (2006). The transformational nature of web-based mediation: Constructing a research agenda for in-service public administration students. Public Performance \& Management Review, 30(2), 245-255.

7. Chiu, C.-M., Hsu, M.-H., Sun, S.-Y., Lin, T.-C., \& Sun, P.-C. (2005). Usability, quality, value and e-learning continuance decisions. Computers and Education, 45(4), 399-416.

8. Coffin, R. J., and MacIntyre, P. D. (1999), Motivational Influences on Computerrelated Affective States. Computers in Human Behavior, 15(5), 549-569.

9. Compeau, D. R., \& Higgins, C. A. (1995). Computer self-efficacy: Development of a measure and initial test. MIS Quarterly, 19(2),189-211.

10. Davis, F. D. (1989). Perceived usefulness, perceived ease of use, and user acceptance of information technology. MIS Quarterly, 14(3), 319-340.

11. Davis, F.D., Bagozzi, R. P., \& Warshaw, P. R. (1992). Extrinsic and intrinsic motivation to use computers in the workplace. Journal of Applied Social Psychology, 22(14), 1111-1132.

12. Dupagne, M., \& Krendl, K. A. (1992). Teachers' attitudes toward computers: A review of literature. Journal of Research on Computing in Education, 24(3), 420-29.

13. Gefen, D., \& Straub, D. W. (2003). Managing user trust in B2C E-services. EService Journal, 2(2), 7-24.

14. Geissler, J. E., \& Horridge, P. (1993). University students' computer knowledge and commitment to learning. Journal of Research on Computing in Education, 25(3), 347-365.

15. Hakkinen, P. (1994). Changes in computer anxiety in a required computer course. Journal of Research on Computing in Education, 27(2), 141-153.

16. Hartwick, J., \& Barki, H. (1994). Explaining the role of user participation in information system use. Management Science, 40(4), 440-465.

17. Hong, W., Thong, J. Y. L., Wong, W. M., \& Tam, K. Y. (2002). Determinants of User Acceptance of Digital Libraries: An Empirical examination of individual characteristics and system characteristics. Journal of Management Information Systems, 29(3), 97-124.

18. Igbaria, M., Iivari, J., \& Maragahh, H. (1995). Why do individuals use computer technology? A Finnish case study. Information and Management, 29(5), 227-238.

19. Igbaria, M., Guimaraes, T., \& Davis, G. B. (1995). Testing the determinants of microcomputer usage via a Structural Equation Model. Journal of Management Information Systems, 11(4), 87-114.

20. Karahanna, E., \& Straub, D. W. (1999). The psychological origins of perceived usefulness and ease-of-use. Information and Management, 35(4), 237-250.

21. Kay, R. H. (1993). An exploration of theoretical and practical foundation for assessing attitudes towards computers: The computer 1ttitude measure (CAM), Computers in Human Behavior, 9(4), 371-386.

22. Lederer, A. L., Maupin, D. J., Sena, M. P., \& Zhuang, Y. (2000). The Technology Acceptance Model and the World Wide Web. Decision Support Systems, 29(3), 269-282. 
23. Levine, T., \& Donitsa-Schmidt, S. (1998). Computer use, confidence, attitudes, and knowledge: A causal analysis. Computers in Human Behavior, 14(1), 125-146.

24. Liaw, S. S., Huang, H. M., \& Chen G. D. (2007). Surveying instructor and learners toward E- learning. Computers and Education, 49(4), 1066-1080.

25. Marcoulides, G. A. (1989). Measuring computer anxiety: The computer anxiety scale. Educational and Psychological Measurement, 49, 733-738.

26. Mikkelsen, A., Øgaard, T., Lindøe, P. H., \& Olsen O. E. (2002). Job characteristics and computer anxiety in the Production Industry. Computers in Human Behavior, 18(3), 223-239.

27. Muhammad A.,, \& Ibrahim M. (1998). The relationship of attitudes to computer utilization: New evidence from a developing nation. Computers in Human Behavior, 14(1), 23-42.

28. Ngai, E. W. T., Poon, J. K. L., \& Chan, Y. H. C. (2007). Empirical examination of adoption of WebCT using TAM. Computers and Education, 48(2), 250-267.

29. Nichols, L. M. (1992). The influence of student computer-ownership and in-home use of achievement in an elementary school computer programming curriculum. Journal of Research on Computing in Education, 8(4), 407-421.

30. Ong, C.S., \& Lai, J.Y. (2006). Gender differences in perceptions and relationships among dominants of e-learning acceptance. Computers in Human Behaviors, 5(22), 816-829.

31. Pituch. A. P., \& Lee, Y. K. (2006). The influence of system characteristics on elearning use. Computers and Education, 47(2), 222-244.

32. Rocheleau, B. (1995). Computer use by school-age children: Trends, patterns, and predictions. Journal of Research on Computing in Education, 12(1), 1-17.

33. Schunk, Dale H. (1996). Learning Theories: An Educational Perspective. PrenticeHall, Inc., Englewood Cliffs: New Jersey.

34. Taylor, S., \& Todd, P. (1995). Assessing IT usage: The role of prior experience. MIS Quarterly, 19(4), 561-570.

35. Teo, H. H., Wei, K. K., \& Benbasat, I. (2003). Predicting intention to adopt interorganizational linkages: An institutional perspective. MIS Quarterly, 27(1), 1949.

36. Torkzadeh, G., \& Van Dyke (2002). Effects of training on internet self-efficacy and computer user attitudes. Computers in Human Behaviors, 18(5), 479-494.

37. Thong, J. K. L. (1999). An integrated model of information systems adopting in small business. Journal of Management Information Systems, 15(4), 187-214.

38. Venkatesh, V., \& Davis, F. D. (1996). A Model of the antecedents of perceived ease of use: Development and test. Decision Sciences, 27(3), 451-481.

39. Venkatesh, V., \& Morris, M. G. (2000). Why don't men ever stop to ask for Directions? Gender, Social Influence, and Their Role in Technology Acceptance and usage behavior. MIS Quarterly, 24(1), 115-139.

40. Yaghi, M. H., \& Abu-Saba, M. B. (1998). Teachers' computer anxiety: An international perspective. Computers in Human Behavior, 14(2), 321-336.

41. Whitely, B. E. Jr. (1997), Gender Differences in Computer Related Attitudes and Behavior: A Meta Analysis, Computers in Human Behavior, 13(1), 1-22.

42. Wixom, B. H., \& Todd, P. A. (2005). A theoretical integration of user satisfaction and technology acceptance. Information Systems Research, 16(1), 85-102. 


\section{Appendix}
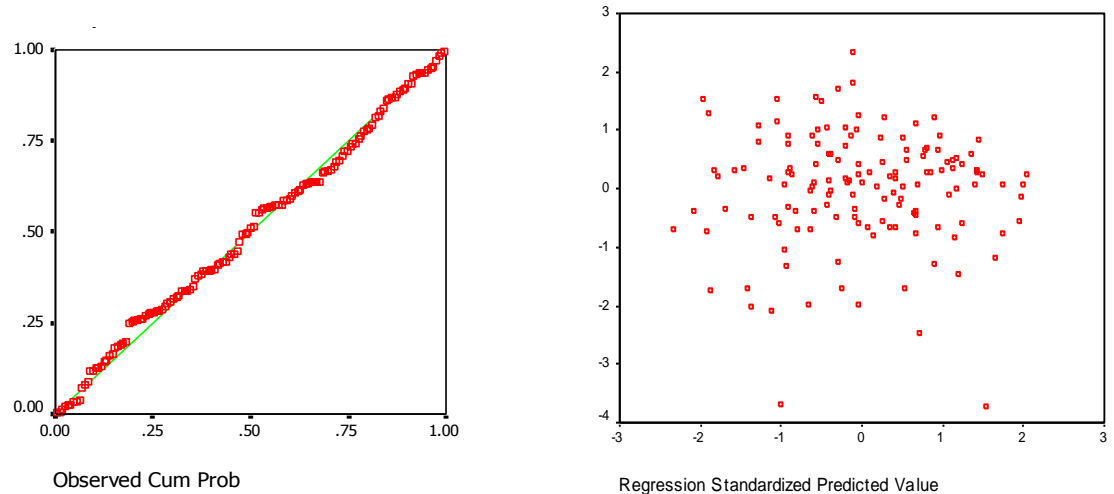

Regression Standardized Predicted Value

Figure A. The Normal Probability Plot and Scatter Plot of Residuals for the Regression Analysis of Intention with Determinants 